\title{
Commentary \\ Molecular Biomarkers of Oxygen Therapy in Patients with Diabetic Foot Ulcers
}

\author{
Alisha R. Oropallo ${ }^{1, *}$, Thomas E. Serena ${ }^{2}\left(\mathbb{D}\right.$, David G. Armstrong ${ }^{3}$ and Mark Q. Niederauer ${ }^{4}$ \\ 1 Comprehensive Wound Healing Center and Hyperbarics, Department of Vascular Surgery, Zucker School \\ of Medicine Hofstra/Northwell, Hempstead, NY 11549, USA \\ 2 Serena Group Research Foundation, Cambridge, MA 02140, USA; serena@serenagroups.com \\ 3 Limb Preservation Program, Department of Surgery, Keck School of Medicine of University of Southern \\ California, Los Angeles, CA 90033, USA; armstrong@usa.net \\ 4 EO2 Concepts, San Antonio, TX 78249, USA; m.niederauer@eo2.com \\ * Correspondence: aoropallo@northwell.edu; Tel.: +1-516-233-3780
}

Citation: Oropallo, A.R.; Serena, T.E.; Armstrong, D.G.; Niederauer, M.Q. Molecular Biomarkers of Oxygen Therapy in Patients with Diabetic Foot Ulcers. Biomolecules 2021, 11, 925. https://doi.org/10.3390/

biom11070925

Academic Editor: Vladimir N. Uversky

Received: 30 May 2021

Accepted: 19 June 2021

Published: 22 June 2021

Publisher's Note: MDPI stays neutral with regard to jurisdictional claims in published maps and institutional affiliations.

Copyright: (c) 2021 by the authors. Licensee MDPI, Basel, Switzerland. This article is an open access article distributed under the terms and conditions of the Creative Commons Attribution (CC BY) license (https:// creativecommons.org/licenses/by/ $4.0 /)$.

\begin{abstract}
Hyperbaric oxygen therapy (HBOT) and topical oxygen therapy (TOT) including continuous diffuse oxygen therapy (CDOT) are often utilized to enhance wound healing in patients with diabetic foot ulcerations. High pressure pure oxygen assists in the oxygenation of hypoxic wounds to increase perfusion. Although oxygen therapy provides wound healing benefits to some patients with diabetic foot ulcers, it is currently performed from clinical examination and imaging. Data suggest that oxygen therapy promotes wound healing via angiogenesis, the creation of new blood vessels. Molecular biomarkers relating to tissue inflammation, repair, and healing have been identified. Predictive biomarkers can be used to identify patients who will most likely benefit from this specialized treatment. In diabetic foot ulcerations, specifically, certain biomarkers have been linked to factors involving angiogenesis and inflammation, two crucial aspects of wound healing. In this review, the mechanism of how oxygen works in wound healing on a physiological basis, such as cell metabolism and growth factor signaling transduction is detailed. Additionally, observable clinical outcomes such as collagen formation, angiogenesis, respiratory burst and cell proliferation are described. The scientific evidence for the impact of oxygen on biomolecular pathways and its relationship to the outcomes in clinical research is discussed in this narrative review.
\end{abstract}

Keywords: oxygen; hyperbaric; topical oxygen; continuous diffusion oxygen; diabetic foot ulcer; molecular biomarkers

\section{Introduction}

Lower extremity complications in people with diabetes constitute a large worldwide burden within in already burdened population [1,2]. Every $1.2 \mathrm{~s}$, someone with diabetes develops a foot ulcer [1]. More than half of these wounds become infected [3-5], leading to a high rate of emergency department visits, hospitalizations and ultimately amputation [6]. Every $20 \mathrm{~s}$, someone with diabetes undergoes an amputation somewhere in the world [7-9]. Patients with diabetic foot ulcers are at a near three-fold greater risk for death in the year following wounding than patients with diabetes without foot ulcers [10]. This increases with additional comorbidities. Following ulceration, Charcot arthropathy, development of chronic limb threatening ischemia or amputation, 5-year mortality is comparable to most cancers [11-13]. Additionally, the costs for care for patients with diabetic foot ulcers exceed the cost of care most individual cancers $[11,14,15]$.

The role of oxygen in wound healing has long garnered interest among researchers and clinicians alike. This interest has only increased as modalities for delivery of oxygen have evolved from large hyperbaric chambers to portable, direct topical application using localized chambers and more recently to handheld, wearable systems which continuously diffuse oxygen directly into the wound bed. There are distinct differences and advantages 
of each modality for oxygen delivery. Although oxygen therapy can be used for a variety of etiologies, the focus of oxygen therapy discussed revolves around its most common usage which is diabetic foot ulcerations due to its element of ischemia, either involving a macro or micro circulatory component. In hyperbaric oxygen therapy (HBOT) a contained chamber is pressurized with $100 \%$ oxygen to $2.0-2.4$ atmospheres absolute for 90 min 5-7 days per week. HBOT relies on respiration and the circulatory system to deliver oxygen to the wound bed [16]. The increased pressure supersaturates the plasma; however, oxygen delivery relies on local capillary structure to reach injured tissues. Deficient or absent capillary beds may impede the oxygen delivery to ischemic tissues. Traditional TOT uses high flow oxygen concentrators coupled with chambers or bags placed directly over or around the wound. TOT applies oxygen directly to the wound, allowing the oxygen to diffuse directly into the wound and is therefore not reliant on underlying capillary structures. TOT follows an intermittent treatment regimen similar to HBOT. Currently, most recent devices are wearable and continuously generate pure, humidified oxygen from surrounding air using electrochemical oxygen generators. There is no need for an external oxygen source. They continuously diffuse oxygen (CDO) directly into wounds ( $24 \mathrm{~h}$ a day, 7 days a week) using an oxygen diffuser or oxygen diffusion dressings. CDOT, like TOT, does not depend on the underlying capillary structure of the wound bed, however, unlike TOT, the continuous application of oxygen resembles physiologic oxygen delivery. The biomolecular evidence for the effects of oxygen in wound healing including all modalities of delivery are presented. Although delivery mechanisms differ, the effect of oxygen at a cellular level is consistent.

However, the availability of oxygen to injured tissues will depend on the method of delivery. For HBOT, which relies on inspired oxygen, the availability depends on arterial pO2, vascular supply, local capillary structures and the diffusion distance for the oxygen from the capillaries to the cells. Both edema and necrotic debris increase the diffusion distance. If the local structures are impaired or vasoconstriction is present, wound perfusion can be significantly impaired such that little to no increase in wound pO2 levels occurs despite breathing supplemental oxygen [17-19]. Hence, there is a need for determining local vascular adequacy using methods such as transcutaneous oxygen pressure measurement prior to initiating HBOT. Modalities that use direct application of oxygen to the wound, such as TOT and CDOT, still require adequate vascular sufficiency, yet are significantly less dependent on local capillary structures. Necrotic tissue increases the diffusion distance to the wound, so debridement is an important step to ensure optimal diffusion of oxygen into the wound bed for topically applied oxygen. Debridement has been shown to have significant benefit when applied to standard moist wound therapies [20-22]. The importance of debridement in topically applied oxygen was recently demonstrated in a double blind, placebo-controlled clinical study, where CDOT showed dramatically higher wound closure rates and overall closure for wounds that were debrided frequently versus those that were not [23] in patients with diabetic foot ulcers.

The molecular processes discussed herein are oxygen dependent and do not occur without oxygen. The reactions are catalyzed by enzymes which typically have about $50 \%$ maximum speed at normal tissue pO2 levels $(40-80 \mathrm{~mm} \mathrm{Hg}$ ) and reach $90 \%$ of maximum speed at levels varying between about $150 \mathrm{~mm} \mathrm{Hg}$ to over $400 \mathrm{~mm} \mathrm{Hg}$ [24,25]. These higher levels can only be achieved with supplemental oxygen. An interesting finding regarding the positive correlation between oxygen concentration and functionality is that the more oxygen there is, the faster and better the outcomes are compared to normal wound healing. The differences are even greater when compared to ischemic wounds which are hypoxic. The definitions of hypoxia and hyperoxia are relative. In the context of this review, they are relative to the levels normally found in healthy tissue surrounding a wound $(40-80 \mathrm{~mm} \mathrm{Hg})$. 


\section{Cell Metabolism and Energy}

Oxygen plays a crucial role in energy production and cell metabolism. In this role, oxygen is required for intracellular processes such as biosynthesis and transport, not to mention cell survival [26]. Oxygen dependent enzymes include adenosine triphosphate (ATP) for chemical energy and nicotinamide adenine dinucleotide phosphate (NADPH) oxygenase for respiratory burst (reactive oxygen species release). ATP fuels most active cellular processes and the increased energy demand of tissue that is undergoing healing leads to a hypermetabolic state wherein additional energy is generated from oxidative metabolism [27-30]. Other metabolic processes such as aerobic glycolysis, B-oxidation of fatty acids and the citric acid cycle are tightly attached to the energy acquisition by oxidative phosphorylation and are, therefore, oxygen dependent [31]. Conversely, when tissue oxygen levels are consistently too low $(<20 \mathrm{mmHg}$ pO2), cells convert to anaerobic metabolism and go into survival mode in which wound healing activities such as mitotic cell division, and, therefore, re-epithelialization with collagen production are impaired [32-34]. Prolonged exposure to extremely low oxygen levels, if not alleviated by oxygen, can result in cell death and tissue necrosis due to the inability of the cells to repair the spontaneous decay of cell components (DNA, RNA and proteins) and inability to maintain calcium pumps which require ATP to function [35,36].

\section{Molecular Biomarkers in Growth Factor Signaling Transduction}

Reactive oxygen species (ROS) are essential for the signaling processes of growth factors and processes such as leukocyte recruitment, cell motility, angiogenesis and extracellular matrix formation involved in wound healing [37]. The rate-limiting substrate for ROS production is oxygen. In a wound site, almost all wound-related cells can generate ROS using the enzyme nicotinamide adenine dinucleotide phosphate (NADPH) oxidase. The functionality of NADPH oxidase correlates positively to $\mathrm{pO} 2$ levels, with the maximal function of NADPH oxidase observed at pO2 $>300 \mathrm{~mm} \mathrm{Hg}$, levels only achievable with supplemental oxygen. In wounds deficient of oxygen, such as diabetic or ischemic wounds, NADPH oxidase ceases to function at pO2 levels below $20 \mathrm{~mm} \mathrm{Hg}$. There have been no noted adverse effects or increased reports of safety issues associated with high concentrations of oxygen in wound care. The increased ROS levels appear to accelerate the signaling processes without causing any damage at the cellular level. On a clinical level, studies have shown comparable or decreased adverse events and hospitalizations compared to standard of care with no supplemental oxygen [38-41].

Signal transduction of growth factors and cytokines is stimulated by ROS [42]. ROS, such as superoxide and hydrogen peroxide, increase vascular endothelial growth factor (VEGF) production in macrophages and keratinocytes [43,44]. ROS are also required for platelet-derived growth factor (PDGF) to regulate cell growth and division [45]. Like VEGF, PDGF plays a significant role in blood vessel formation (angiogenesis) [46]. ROS have effects on other processes such as cytokine action, cell motility and extracellular matrix formation [47]. Conversely, tissue hypoxia will limit redox signaling and disable the function of several growth factors such as PDGF, VEGF, keratinocyte growth factor, insulin-like growth factor one (IGF-1), transforming growth factor beta (TFG- $\beta$ ) and numerous molecular mechanisms (e.g., leukocyte recruitment, cell motility and integrin function) which rely on redox signaling $[37,48,49]$. This positive correlation between $\mathrm{pO} 2$ levels, ROS production, and growth factor promotion of cytokine expression explains why ischemic diabetic wounds, having little to no ROS, fail to heal and why wounds supplemented with oxygen heal faster. Typical molecular biomarkers that are indicative of wound healing are shown in Table 1 along with the processes that they are associated with. These biomarkers and their effects on wound healing will be discussed in greater detail throughout this review. 
Table 1. Molecular Biomarkers and Clinical Impact in Wound Healing.

\begin{tabular}{cr}
\hline & Growth Factors \\
\hline IGF-1 & protein production and cell proliferation and migration \\
\hline PDGF & cell growth and division and chemotaxis \\
\hline TGF- $\beta$ & $\begin{array}{r}\text { angiogenesis, fibroblast proliferation, collagen synthesis and deposition, } \\
\text { extracellular matrix (ECM) remodeling, tissue remodeling, granulation tissue } \\
\text { stimulant and anti-inflammatory mediator }\end{array}$ \\
\hline VEGF & angiogenesis and collagen deposition and epithelialization \\
\hline IGF-1 & protein production and cell proliferation and migration \\
\hline CXCL8 & angiogenesis, epithelialization, fibroblast migration and inflammatory mediator \\
\hline IL-6 & leukocyte infiltration, angiogenesis, collagen accumulation, anti-inflammatory, \\
granulation tissue stimulant and mitogenic
\end{tabular}

The impact of continuous diffusion of oxygen therapy (CDOT) on wound cytokines and growth factors was recently demonstrated in a prospective study of 23 patients with diabetic foot ulcers below the malleolus [50]. Results showed significant increases in growth factors, cytokines and transcutaneous oxygen pressure measurement levels after application of CDOT. Growth factors significantly increased from $280 \%$ to $820 \%$ of base levels in the first week and decreased in subsequent weeks [50] (Figure 1). Cytokines increased significantly (up to $680 \%$ compared to baseline levels) in the first two weeks and then decreased. Significant increases in transcutaneous oxygen pressure measurement indicated increased oxygen perfusion in the wound periphery. This is evidence that the topically applied oxygen not only saturated the wound bed, yet also elevated the levels of oxygen in the surrounding tissues.

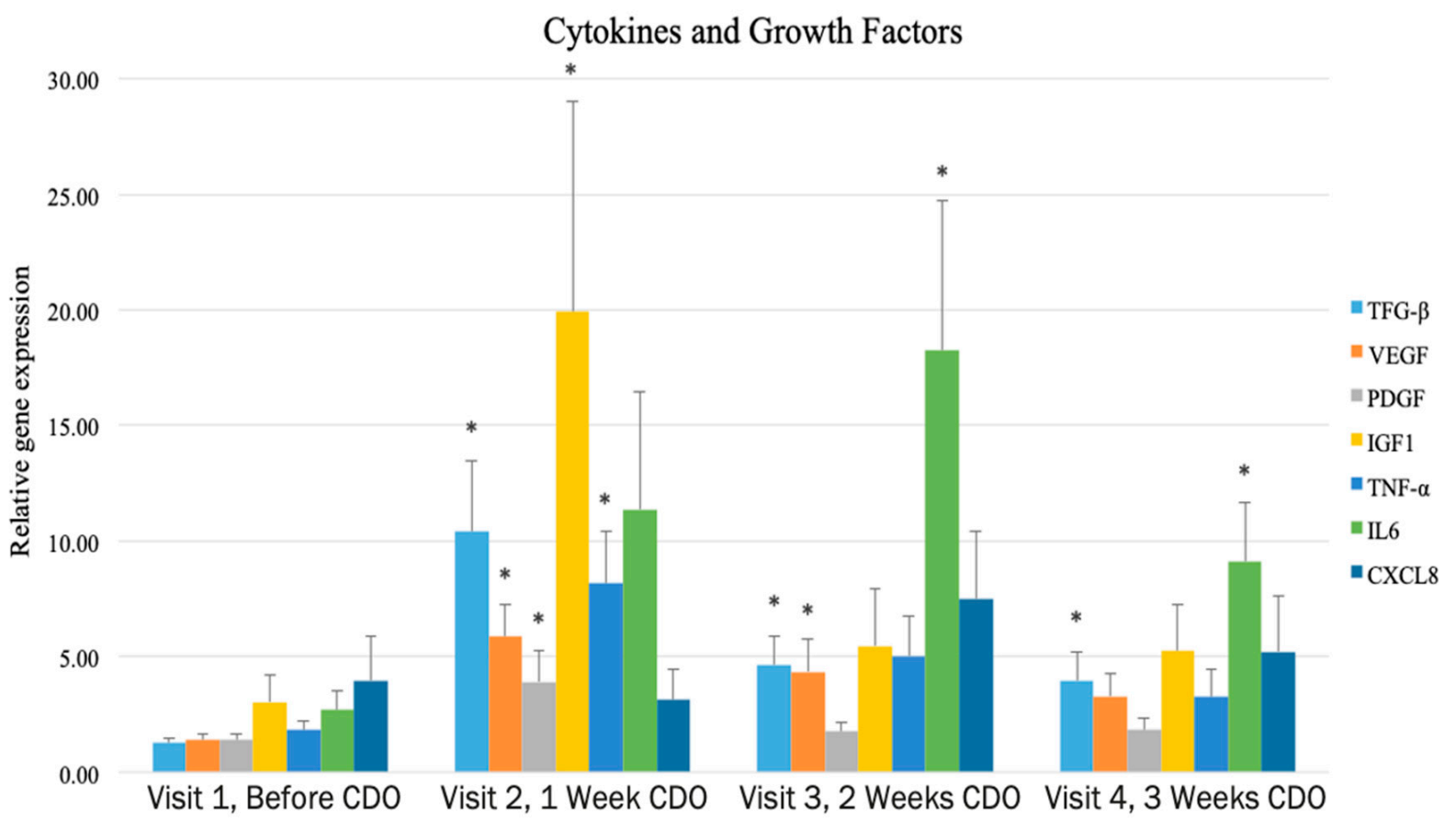

Figure 1. Impact of $\mathrm{CDO}$ on gene expression for various cytokines and growth factors at each visit Asterisks indicate significant increase from baseline [50]. Adapted with permission. 


\section{Collagen Formation}

Oxygen is essential to make and properly organize collagen, which is the primary component of skin, accounting for $70-80 \%$ of dry weight and acts as the primary structural scaffold of skin and structures the matrix for angiogenesis. Organized collagen is bundled into fibers, which are interwoven and can be stretched in multiple directions without tearing. At the biomolecular level, oxygen is required for the hydroxylation of proline and lysine in procollagen [51]. Several posttranslational steps in collagen synthesis are oxygen dependent. The enzymes prolyl hydroxylase, lysyl hydroxylase and lysyl oxidase all require oxygen $[46,52,53]$. The formation of cross-linked triple-helices occurs via the oxygen-dependent enzyme prolyl hydroxylase and are excreted as collagen fibers. Collagen fibers are arranged into linear fibrils via cross-linking by lysyl hydroxylase. Linear fibrils are cross-linked by lysyl oxidase-a necessary step to achieve the necessary tensile strength for healed wounds.

Higher oxygen concentrations increase the amount of collagen deposition [54] and tensile strength [55-57]. The rate limiting step is the rate of prolyl hydroxylation $[52,53]$. The oxygen level required for optimal prolyl hydryoxlase activity is at oxygen levels approaching $250 \mathrm{mmHg}$, exceeding those present in normal wounds and only achievable using oxygen therapy treatment $[58,59]$. It has been shown that increasing oxygen concentrations above normal physiologic levels enhances collagen synthesis and tensile strength in both animal and human subjects [55-57] and can increase the level of collagen organization [60]. Correction of vasoconstriction and hypoxia can result in a 10-fold increase in collagen deposition in wound repair $[17,54,56,61]$. The rates of collagen deposition increase as oxygen levels increase, with optimal activity at levels higher than $250 \mathrm{mmHg}$ [62]. Conversely, hypoxic wounds as in patients with diabetes deposit collagen poorly and become infected easily [51,54],

In a study using supplemental oxygen at a rate of $4 \mathrm{~L} / \mathrm{min}$ through nasal cannula for $12 \mathrm{~h}$ a day for 3 days, it was found that three times as much collagen was deposited in patients with well-perfused and oxygenated wounds compared with those with lower oxygenation and perfusion scores [54]. A separate study using direct topical oxygen on chronic diabetic foot ulcers showed significant increases in the expression of genes associated with collagen production (TGF- $\beta$, VEGF and IL-6) during weekly follow-up visits after application of $\mathrm{CDO}$ in patients with diabetic foot ulcers [50].

\section{Angiogenesis Biomarkers}

The creation of new blood vessels, angiogenesis, is essential to the growth and survival of repair tissue. Oxygen levels directly affect not only the rate, yet also the quality of new blood vessel growth. Sufficient oxygen levels are required for correct collagen synthesis (posttranslational hydroxylation) [63] without which the new capillary tubes assemble poorly and remain fragile $[62,64,65]$. Supplemental oxygen has been shown to accelerate blood vessel growth [66]. Moderate hyperoxia increases the appearance of new blood vessels in wounds [67]. Similar to ROS activity, the rate of angiogenesis has been shown to be directly proportional to oxygen levels in damaged tissues [62], with maximum activity levels at pO2 levels exceeding $250 \mathrm{~mm} \mathrm{Hg}$.

VEGF has been shown to be a major long-term angiogenic stimulus at the wound site and is believed to be most prevalent and efficacious signal for angiogenesis. Oxygen treatment induces VEGF mRNA levels in endothelial cells and macrophages [68-70] and VEGF 121/165 protein expression in wounds [71]. Oxygen has also been shown to facilitate the release of VEGF165 from cell-associated stores [72].

Hyperbaric and topical oxygen therapy have been shown to increase VEGF expression in wounds [73] and induce angiogenesis [74]. More recently, a clinical study on gene expression of multiple factors involved in angiogenesis (VEGF, TGF- $\beta$, IL- 6 and CXCL8) showed significant increases upon continuous application of oxygen (Figure 1) [50]. The expression levels over time are similar to gross observations of their effect in the field: increased redness within the first week and exudate levels that peak within the first 
two weeks and then subside, both indicators of new capillary formation. Furthermore, the curved response shown in Figure 1 reflects what would be expected of a chronic wound "reawakening" and entering the inflammatory stage.

\section{Respiratory Burst Process and Cytokine Production}

Oxygen is essential for respiratory burst, or the production of reactive oxygen species (ROS), used by phagocytes such as neutrophils and macrophages in bactericidal activity and the removal of necrotic cellular debris. NADPH oxidase, also known as leukocyte oxidase, has been shown to support macrophage survival, a delay of apoptosis and enables dead cell cleansing by phagocytosis [75]. NADPH oxidase in wound phagocytes, such as neutrophils and macrophages, produces superoxides (O2- and $\mathrm{H} 2 \mathrm{O} 2)$ for bactericidal activities [76]. It has been shown that up to $98 \%$ of oxygen consumed by these cells is used to produce ROS during phagocytosis [24]. Leukocyte activity, which involves the production of ROS which enables oxidative killing, is directly proportional to local oxygen concentration $[77,78]$. The optimal ROS production is seen at oxygen levels of greater than $300 \mathrm{mmHg}$, levels which can only be achieved with supplemental oxygen [79]. ROS activity is not restricted to phagocytes. At the wound site, ROS are generated by almost all wound-related cells [46]. The efficacy of supplemental oxygen has been shown to be similar to antibiotic administration and has additive effects when used together $[80,81]$.

Interleukins are a type of cytokine protein that play important roles in the differentiation/activation of immune cells in addition to their proliferation, maturation, migration and adhesion. [https: / / www.ncbi.nlm.nih.gov/books /NBK499840/ StatPearls Publishing; 31 January 2021]. The addition of continuous oxygen therapy directly to a wound has been shown to increaseIL-6 significantly (up to $680 \%$ relative to baseline) in clinical studies [50,82]. IL-6 has been shown to induce chemotaxis of leukocytes into a wound $[83,84]$. As inflammation progresses, IL-6 signaling is responsible for the switch to a reparative environment.

\section{Cell Proliferation Molecular Markers}

Increasing oxygen levels results in faster cell proliferation, re-epithelialization and collagen formation. Fibroblast proliferation and protein production have been reported to be optimal at $160 \mathrm{mmHg}$, i.e., at pO2 levels two-fold to three-fold higher than those found in healthy tissues [85], indicating that supplemental oxygen increases the rate of wound repair. Endothelial progenitor cells (EPCs) are essential in wound healing, but their circulating and wound level numbers are decreased in diabetes. Elevated oxygen levels (hyperoxia) reverse the diabetic defect in EPC mobilization [86]. EPC mobilization into circulation is triggered by hyperoxia through induction of nitric oxide with resulting enhancement in ischemic limb perfusion and diabetic wound healing [87-89].

Matrix metalloproteinases (MMPs) are a group of enzymes responsible for degrading a majority of extracellular matrix proteins during tissue development, growth and turnover [90,91]. MMPs have diagnostic, predictive and indicative power for wound healing and can be measured from wound fluid. They are required for a wound to heal properly, at a suitable level, in the correct position and for a certain length of time. Excess activity may lead to a chronic non healing wound. Chronically increased levels of MMPs and reduced levels of TIMPs (MMP regulators), or just abnormalities in their ratio, are associated with non-healing. Studies show that medical interventions which aid in lowering MMP activity will promote the healing of stalled wounds and that decreasing MMP-2 tissue levels will result in wound healing. In one study elevated MMP-1 and TIMP-1 levels were noted in on oxygen treatment group, yet not in the control group [82].

At the clinical level, the cumulative effects of oxygen in all the various aspects discussed herein result in significant real-world results. In a clinical study which analyzed VEGF expression versus wound size reduction using TOT, a significant correlation between wound closure and VEGF expression was found [73]. Recent results using topically applied oxygen therapy, both continuously and intermittently, on diabetic foot wounds 
has been shown to increase the rate of wound closure, by as much as $460 \%$ relative to moist wound therapy in several double-blinded trials, two of which had placebo control groups [23,38-41]. As would be predicted by the positive correlation of various mechanisms of action to the relative concentration of oxygen, wounds that were larger, deeper, more chronic and weight-bearing had improved responses relative to controls than those that were smaller, shallower, less chronic or non-weight-bearing, respectively [38].

\section{Summary}

Biomolecular pathways associated with wound care have been shown to be positively correlated to local tissue oxygen concentration. Maximal activity levels of the related enzymes, growth factors and cytokines, as well as the associated physiological processes, are significantly above the levels normally found in healthy tissues. The positive, differential effect from supplemental oxygen has been shown to be even higher for tissues with compromised blood supply leading to ischemic diabetic wounds. Increasing the levels of oxygen in afflicted tissues significantly increases not only the rate, yet also the quality of tissue repair. These elevated levels of oxygen can only be achieved through supplemental oxygen therapy, whether it be respiratory based (HBOT) or directly applied to the wound (TOT, CDOT), all of which are reliant on diffusion gradients. The recent research on the scientific basis and clinical outcomes of oxygen therapy lays a foundation for further research in molecular biomarkers utilizing oxygen therapy.

Author Contributions: Conceptualization, A.R.O., M.Q.N.; resources, A.R.O., T.E.S., D.G.A. and M.Q.N.; data curation, A.R.O., T.E.S., D.G.A. and M.Q.N.; writing—original draft preparation, A.R.O. and M.Q.N.; writing-review and editing, A.R.O., T.E.S., D.G.A. and M.Q.N. All authors have read and agreed to the published version of the manuscript.

Funding: This research received no external funding.

Institutional Review Board Statement: Not applicable.

Informed Consent Statement: Not applicable.

Data Availability Statement: Data available on PubMed.

Conflicts of Interest: Authors ARO and TES s declare no conflict of interest. MQN is an employee of EO2 Concepts. DGA is a member of the Scientific Advisory Board of EO2 concepts.

\section{References}

1. Armstrong, D.G.; Boulton, A.J.M.; Bus, S.A. Diabetic Foot Ulcers and Their Recurrence. N. Engl. J. Med. 2017, 376, 2367-2375. [CrossRef] [PubMed]

2. Zhang, Y.; Lazzarini, P.A.; McPhail, S.M.; Van Netten, J.J.; Armstrong, D.G.; Pacella, R.E. Global Disability Burdens of DiabetesRelated Lower-Extremity Complications in 1990 and 2016. Diabetes Care 2020, 43, 964-974. [CrossRef] [PubMed]

3. Lipsky, B.A.; Senneville, É.; Urbančič-Rovan, V.; Peters, E.J.; on behalf of the International Working Group on the Diabetic Foot(IWGDF); Abbas, Z.G.; Aragón-Sánchez, J.; Diggle, M.; Embil, J.M.; Kono, S.; et al. Guidelines on the diagnosis and treatment of foot infection in persons with diabetes (IWGDF 2019 update). Diabet. Metab. Res. Rev. 2020, 36 (Suppl. 1), e3280. [CrossRef] [PubMed]

4. Armstrong, D.G.; A Lavery, L.; Frykberg, R.G.; Wu, S.C.; Boulton, A.J. Validation of a diabetic foot surgery classification. Int. Wound J. 2006, 3, 240-246. [CrossRef]

5. Skrepnek, G.H.; Armstrong, D.G.; Mills, J.L. 2,500,000 Troubled Soles: Ten-Year Analysis of Diabetic Foot Infections in the United States. J. Vasc. Surg. 2013, 58, 558. [CrossRef]

6. Skrepnek, G.H.; Mills, J.L., Sr.; Armstrong, D.G. A Diabetic Emergency One Million Feet Long: Disparities and Burdens of Illness among Diabetic Foot Ulcer Cases within Emergency Departments in the United States, 2006-2010. PLoS ONE 2015, 10, e0134914. [CrossRef]

7. Armstrong, D.G.; A Lavery, L.; Harkless, L.B.; Van Houtum, W.H. Amputation and reamputation of the diabetic foot. J. Am. Podiatr. Med. Assoc. 1997, 87, 255-259. [CrossRef]

8. Lipsky, B.A.; Berendt, A.R.; Cornia, P.B.; Pile, J.C.; Peters, E.J.G.; Armstrong, D.G.; Deery, H.G.; Embil, J.M.; Joseph, W.S.; Karchmer, A.W.; et al. Executive Summary: 2012 Infectious Diseases Society of America Clinical Practice Guideline for the Diagnosis and Treatment of Diabetic Foot Infections. Clin. Infect. Dis. 2012, 54, 1679-1684. [CrossRef] [PubMed]

9. Boulton, A.J.; Armstrong, D.G.; Kirsner, R.S.; Attinger, C.E.; Lavery, L.A.; Lipsky, B.A.; Mills, J.L.; Steinberg, J.S. Diagnosis and Management of Diabetic Foot Complications; American Diabetes Association: Arlington, VA, USA, 2018. [CrossRef] 
10. Saluja, S.; Anderson, S.G.; Hambleton, I.; Shoo, H.; Livingston, M.; Jude, E.B.; Lunt, M.; Dunn, G.; Heald, A.H. Foot ulceration and its association with mortality in diabetes mellitus: A meta-analysis. Diabet. Med. 2020, 37, 211-218. [CrossRef]

11. Armstrong, D.G.; Swerdlow, M.A.; Armstrong, A.A.; Conte, M.S.; Padula, W.V.; Bus, S.A. Five year mortality and direct costs of care for people with diabetic foot complications are comparable to cancer. J. Foot Ankle Res. 2020, 13, 16. [CrossRef]

12. Conte, M.S.; Bradbury, A.W.; Kolh, P.; White, J.V.; Dick, F.; Fitridge, R.; Mills, J.L.; Ricco, J.-B.; Suresh, K.R.; Murad, M.H.; et al. Global vascular guidelines on the management of chronic limb-threatening ischemia. J. Vasc. Surg. 2019, 69, 3S-125S.e40. [CrossRef]

13. Mills, J.L., Sr.; Conte, M.S.; Armstrong, D.G.; Pomposelli, F.B.; Schanzer, A.; Sidawy, A.N.; Andros, G. Society for Vascular Surgery Lower Extremity Guidelines Committee. The Society for Vascular Surgery Lower Extremity Threatened Limb Classification System: Risk stratification based on Wound, Ischemia, and foot Infection (WIfI). J. Vasc. Surg. 2014, 59, $220-234 . e 2$. [CrossRef] [PubMed]

14. Nussbaum, S.R.; Carter, M.J.; Fife, C.E.; DaVanzo, J.; Haught, R.; Nusgart, M.; Cartwright, D. An Economic Evaluation of the Impact, Cost, and Medicare Policy Implications of Chronic Nonhealing Wounds. Value Health 2018, 21, 27-32. [CrossRef]

15. Barshes, N.R.; Sigireddi, M.; Wrobel, J.S.; Mahankali, A.; Robbins, J.M.; Kougias, P.; Armstrong, D.G. The system of care for the diabetic foot: Objectives, outcomes, and opportunities. Diabet. Foot Ankle 2013, 4, 21847. [CrossRef] [PubMed]

16. Howard, M.A.; Asmis, R.; Evans, K.K.; Mustoe, T.A. Oxygen and wound care: A review of current therapeutic modalities and future direction. Wound Repair Regen. 2013, 21, 503-511. [CrossRef]

17. Hopf, H.W.; Hunt, T.K.; West, J.M.; Blomquist, P.; Goodson, W.; Jensen, J.; Jonsson, K.; Paty, P.B.; Rabkin, J.M.; Upton, R.A.; et al. Wound Tissue Oxygen Tension Predicts the Risk of Wound Infection in Surgical Patients. Arch. Surg. 1997, 132, 997-1004. [CrossRef] [PubMed]

18. Gottrup, F.; Firmin, R.; Rabkin, J.; Halliday, B.J.; Hunt, T.K. Directly measured tissue oxygen tension and arterial oxygen tension assess tissue perfusion. Crit. Care Med. 1987, 15, 1030-1036. [CrossRef]

19. Hopf, H.; West, J.; Hunt, T. Clonidine increases tissue oxygen in patients with local tissue hypoxia in non-healing wounds. Wound Repair Regen. 1996, 4, A129.

20. Edwards, J.; Stapley, S. Debridement of diabetic foot ulcers. Cochrane Database Syst. Rev. 2010, CD003556. [CrossRef]

21. Armstrong, D.G.; Lavery, L.A.; Nixon, B.P.; Boulton, A.J.M. It's Not What You Put On, but What You Take Off: Techniques for Debriding and Off-Loading the Diabetic Foot Wound. Clin. Infect. Dis. 2004, 39, S92-S99. [CrossRef]

22. Lebrun, E.; Tomic-Canic, M.; Kirsner, R.S. The role of surgical debridement in healing of diabetic foot ulcers. Wound Repair Regen. 2010, 18, 433-438. [CrossRef] [PubMed]

23. Lavery, L.A.; Niederauer, M.Q.; Papas, K.K.; Armstrong, D.G. Does Debridement Improve Clinical Outcomes in People with DFU Ulcers Treated with CDO? Wounds 2019, 31, 246-251. [PubMed]

24. Allen, D.B.; Maguire, J.J.; Mahdavian, M.; Wicke, C.; Marcocci, L.; Scheuenstuhl, H.; Chang, M.; Le, A.X.; Hopf, H.W.; Hunt, T.K. Wound Hypoxia and Acidosis Limit Neutrophil Bacterial Killing Mechanisms. Arch. Surg. 1997, 132, 991-996. [CrossRef] [PubMed]

25. Hopf, H.W.; Humphrey, L.M.; Puzziferri, N.; West, J.M.; Attinger, C.E.; Hunt, T.K. Adjuncts to preparing wounds for closure: Hyperbaric oxygen, growth factors, skin substitutes, negative pressure wound therapy (vacuum-assisted closure). Foot Ankle Clin. 2001, 6, 661-682. [CrossRef]

26. Sen, C.K. Wound healing essentials: Let there be oxygen. Wound Repair Regen. 2009, 17, 1-18. [CrossRef]

27. Gupta, A.; Raghubir, R. Energy metabolism in the granulation tissue of diabetic rats during cutaneous wound healing. Mol. Cell. Biochem. 2005, 270, 71-77. [CrossRef]

28. Hohn, D.C.; Ponce, B.; Burton, R.W.; Hunt, T.K. Antimicrobial systems of the surgical wound. I. A comparison of oxidative metabolism and microbicidal capacity of phagocytes from wounds and from peripheral blood. Am. J. Surg. 1977, 133, 597-600. [CrossRef]

29. Matsuda, T.; Clark, N.; Hariyani, G.D.; Bryant, R.S.; Hanumadass, M.L.; Kagan, R.J. The Effect of Burn Wound Size on Resting Energy Expenditure. J. Trauma Inj. Infect. Crit. Care 1987, 27, 115-118. [CrossRef]

30. Im, M.J.; Hoopes, J.E. Energy metabolism in healing skin wounds. J. Surg. Res. 1970, 10, 459-464. [CrossRef]

31. Tandara, A.A.; Mustoe, T.A. Oxygen in Wound Healing? More than a Nutrient. World J. Surg. 2004, 28, 294-300. [CrossRef]

32. LaVan, F.B.; Hunt, T.K. Oxygen and Wound Healing. Clin. Plast. Surg. 1990, 17, 463-472. [CrossRef]

33. Hess, C.L.; Howard, M.A.; Attinger, C.E. A Review of Mechanical Adjuncts in Wound Healing: Hydrotherapy, Ultrasound, Negative Pressure Therapy, Hyperbaric Oxygen, and Electrostimulation. Ann. Plast. Surg. 2003, 51, 210-218. [CrossRef]

34. Hunt, T.K. Basic Principles of Wound Healing. J. Trauma Inj. Infect. Crit. Care 1990, 30, 122-128. [CrossRef]

35. Milton, S.L.; Prentice, H.M. Beyond anoxia: The physiology of metabolic downregulation and recovery in the anoxia-tolerant turtle. Comp. Biochem. Physiol. Part A Mol. Integr. Physiol. 2007, 147, 277-290. [CrossRef] [PubMed]

36. Stys, P.K.; Ransom, B.R.; Waxman, S.G.; Davis, P.K. Role of extracellular calcium in anoxic injury of mammalian central white matter. Proc. Natl. Acad. Sci. USA 1990, 87, 4212-4216. [CrossRef]

37. Sen, C.K.; Roy, S. Redox signals in wound healing. Biochim. Biophys. Acta (BBA) Gen. Subj. 2008, 1780, 1348-1361. [CrossRef] [PubMed]

38. Niederauer, M.Q.; Michalek, J.E.; Liu, Q.; Papas, K.K.; Lavery, L.A.; Armstrong, D.G. Continuous diffusion of oxygen improves diabetic foot ulcer healing when compared with a placebo control: A randomised, double-blind, multicentre study. J. Wound Care 2018, 27, S30-S45. [CrossRef] 
39. Frykberg, R.G.; Franks, P.; Edmonds, M.; Brantley, J.N.; Téot, L.; Wild, T.; Garoufalis, M.G.; Lee, A.M.; Thompson, J.A.; Reach, G.; et al. A Multinational, Multicenter, Randomized, Double-Blinded, Placebo-Controlled Trial to Evaluate the Efficacy of Cyclical Topical Wound Oxygen (TWO2) Therapy in the Treatment of Chronic Diabetic Foot Ulcers: The TWO2 Study. Diabetes Care 2019, 43, 616-624. [CrossRef]

40. Serena, T.E.; Bullock, N.M.; Cole, W.; Lantis, J.; Li, L.; Moore, S.; Patel, K.; Sabo, M.; Wahab, N.; Price, P. Topical oxygen therapy in the treatment of diabetic foot ulcers: A multicentre, open, randomised controlled clinical trial. J. Wound Care 2021, 30, S7-S14. [CrossRef]

41. Yu, J.; Lu, S.; McLaren, A.-M.; Perry, J.A.; Cross, K.M. Topical oxygen therapy results in complete wound healing in diabetic foot ulcers. Wound Repair Regen. 2016, 24, 1066-1072. [CrossRef]

42. Sundaresan, M.; Yu, Z.-X.; Ferrans, V.J.; Sulciner, D.J.; Gutkind, J.S.; Irani, K.; Goldschmidt-Clermont, P.J.; Finkel, T. Regulation of reactive-oxygen-species generation in fibroblasts by Rac 1. Biochem. J. 1996, 318, 379-382. [CrossRef]

43. Sen, C.K.; Khanna, S.; Babior, B.M.; Hunt, T.K.; Ellison, E.C.; Roy, S. Oxidant-induced Vascular Endothelial Growth Factor Expression in Human Keratinocytes and Cutaneous Wound Healing. J. Biol. Chem. 2002, 277, 33284-33290. [CrossRef] [PubMed]

44. Cho, M.; Hunt, T.K.; Hussain, M.Z. Hydrogen peroxide stimulates macrophage vascular endothelial growth factor release. Am. J. Physiol. Circ. Physiol. 2001, 280, H2357-H2363. [CrossRef]

45. Sundaresan, M.; Yu, Z.-X.; Ferrans, V.J.; Irani, K.; Finkel, T. Requirement for generation of $\mathrm{H}_{2} \mathrm{O}_{2}$ for platelet-derived growth factor signal transduction. Science 1995, 270, 296-299. [CrossRef] [PubMed]

46. Gordillo, G.M.; Sen, C.K. Revisiting the essential role of oxygen in wound healing. Am. J. Surg. 2003, 186, 259-263. [CrossRef]

47. Sen, C.K. The general case for redox control of wound repair. Wound Repair Regen. 2003, 11, 431-438. [CrossRef] [PubMed]

48. Roy, S.; Khanna, S.; Sen, C.K. Redox regulation of the VEGF signaling path and tissue vascularization: Hydrogen peroxide, the common link between physical exercise and cutaneous wound healing. Free Radic. Biol. Med. 2008, 44, 180-192. [CrossRef]

49. Roy, S.; Khanna, S.; Rink, C.; Biswas, S.; Sen, C.K. Characterization of the acute temporal changes in excisional murine cutaneous wound inflammation by screening of the wound-edge transcriptome. Physiol. Genom. 2008, 34, 162-184. [CrossRef] [PubMed]

50. Lavery, L.A.; Killeen, A.L.; Farrar, D.; Akgul, Y.; Crisologo, P.A.; Malone, M.; Davis, K.E. The effect of continuous diffusion of oxygen treatment on cytokines, perfusion, bacterial load, and healing in patients with diabetic foot ulcers. Int. Wound J. 2020, 17, 1986-1995. [CrossRef]

51. Hunt, T.K.; Zederfeldt, B.; Goldstick, T.K. Oxygen and healing. Am. J. Surg. 1969, 118, 521-525. [CrossRef]

52. Prockop, D.; Kivirikko, K.; Tuderman, L.; Guzman, N. The biosynthesis of collagen and its disorders (part 1). N. Engl. J. Med. 1979, 301, 13-23. [CrossRef]

53. Prockop, D.; Kivirikko, K.; Tuderman, L.; Guzman, N. The biosynthesis of collagen and its disorder (part 2). N. Engl. J. Med. 1979, 301, 77-85. [CrossRef] [PubMed]

54. Jonsson, K.; Jensen, J.; Goodson, W.; Scheuenstuhl, H.; West, J.; Hopf, H.; Hunt, T. Tissue oxygenation, anemia, and perfusion in relation to wound healing in surgical patients. Ann. Surg. 1991, 214, 605-613. [CrossRef] [PubMed]

55. Niinikoski, J. Effect of oxygen supply on wound healing and formation of experimental granulation tissue. Acta Physiol. Scand. Suppl. 1969, 334, 1-72.

56. Hunt, T.K.; Pai, M.P. The effect of varying ambient oxygen tensions on wound metabolism and collagen synthesis. Surg. Gynecol. Obstet. 1972, 135, 561-567. [PubMed]

57. Stephens, F.O.; Hunt, T.K. Effect of Changes in Inspired Oxygen and Carbon Dioxide Tensions on Wound Tensile Strength. Ann. Surg. 1971, 173, 515-519. [CrossRef]

58. Hutton, J.J.; Tappel, A.; Udenfriend, S. Cofactor and substrate requirements of collagen proline hydroxylase. Arch. Biochem. Biophys. 1967, 118, 231-240. [CrossRef]

59. Myllyla, R.; Tuderman, L.; Kivirikko, K. Mechanism of the prolyl hydroxlase reaction. 2. Kinetic analysis of the reaction se-quence. Eur. J. Biochem. 1977, 80, 349-357. [CrossRef]

60. Asmis, R.; Qiao, M.; Zhao, Q. Low-Flow Oxygenation of Full-Excisional Skin Wounds on Diabetic Mice Improves Wound Heal-ing by Accelerating Wound Closure and Reepithelialization. Int. Wound J. 2010, 7, 349-357. [CrossRef]

61. Hartmann, M.; Jönsson, K.; Zederfeldt, B. Effect of tissue perfusion and oxygenation on accumulation of collagen in healing wounds. Randomized study in patients after major abdominal operations. Eur. J. Surg. 1992, 158, 521-526.

62. Hopf, H.W.; Gibson, J.J.; Angeles, A.P.; Constant, J.S.; Feng, J.J.; Rollins, M.D.; Zamirul Hussain, M.; Hunt, T.K. Hyperoxia and angiogenesis. Wound Repair Regen. 2005, 13, 558-564. [CrossRef] [PubMed]

63. Mussini, E.; Hutton, J.J., Jr.; Udenfriend, S. Collagen proline hydroxylase in wound healing, granuloma formation, scurvy, and growth. Science 1967, 157, 927-929. [CrossRef]

64. Berthod, F.; Germain, L.; Tremblay, N.; Auger, F.A. Extracellular matrix deposition by fibroblasts is necessary to promote capil-lary-like tube formation in vitro. J. Cell. Physiol. 2006, 207, 491-498. [CrossRef] [PubMed]

65. Hunt, T.K.; Aslam, R.S.; Beckert, S.; Wagner, S.; Ghani, Q.P.; Hussain, M.Z.; Roy, S.; Sen, C.K. Aerobically derived lactate stimulates re-vascularization and tissue repair via redox mechanisms. Antioxid. Redox Signal. 2007, 9, 1115-1124. [CrossRef]

66. Knighton, D.R.; Silver, I.A.; Hunt, T.K. Regulation of wound-healing angiogenesis-effect of oxygen gradients and inspired oxygen concentration. Surgery 1981, 90, 262-270. [PubMed]

67. Sheikh, A.Y.; Rollins, M.D.; Hopf, H.W.; Hunt, T.K. Hyperoxia improves microvascular perfusion in a murine wound model. Wound Repair Regen. 2005, 13, 303-308. [CrossRef] 
68. Maniscalco, W.M.; Watkins, R.H.; Finkelstein, J.N.; Campbell, M.H. Vascular endothelial growth factor mRNA increases in alveolar epithelial cells during recovery from oxygen injury. Am. J. Respir. Cell Mol. Biol. 1995, 13, 377-386. [CrossRef]

69. Deaton, P.R.; McKellar, C.T.; Culbreth, R.; Veal, C.F.; Cooper, J.A. Hyperoxia stimulates interleukin-8 release from alveolar macrophages and U937 cells: Attenuation by dexamethasone. Am. J. Physiol. Lung Cell. Mol. Physiol. 1994, 267, 187-192. [CrossRef]

70. Darrington, R.S.; Godden, D.J.; Park, M.S.; Ralston, S.H.; Wallace, H.M. The effect of hyperoxia on the expression of cytokine mRNA in endothelial cells. Biochem. Soc. Trans. 1997, 25, 292S. [CrossRef]

71. Sheikh, A.Y.; Gibson, J.J.; Rollins, M.D.; Hopf, H.W.; Hussain, Z.; Hunt, T.K. Effect of Hyperoxia on Vascular Endothelial Growth Factor Levels in a Wound Model. Arch. Surg. 2000, 135, 1293-1297. [CrossRef]

72. Shenberger, J.S.; Zhang, L.; Powell, R.J.; Barchowsky, A. Hyperoxia enhances VEGF release from A549 cells via post-transcriptional processes. Free Radic. Biol. Med. 2007, 43, 844-852. [CrossRef]

73. Gordillo, G.M.; Roy, S.; Khanna, S.; Schlanger, R.; Khandelwal, S.; Phillips, G.; Sen, C.K. Topical oxygen therapy induces vascular endothelial growth factor expression and im-proves closure of clinically presented chronic wounds. Clin. Exp. Pharmacol. Physiol. 2008, 35, 957-964. [CrossRef]

74. Heng, M.C.; Harker, J.; Csathy, G.; Marshall, C.; Brazier, J.; Sumampong, S.; Paterno Gomez, E. Angiogenesis in necrotic ulcers treated with hyperbaric oxygen. Ostomy Wound Manag. 2000, 46, 18-28.

75. Brown, J.R.; Goldblatt, D.; Buddle, J.; Morton, L.; Thrasher, A.J. Diminished production of anti-inflammatory mediators during neutrophil apoptosis and macrophage phagocytosis in chronic granulomatous disease (CGD). J. Leukoc. Biol. 2003, 73, 591-599. [CrossRef]

76. Babior, B.M. Oxygen-dependent microbial killing by phagocytes (first of two parts). N. Engl. J. Med. 1978, 298, 659-668. [CrossRef] [PubMed]

77. Rabkin, J.M.; Hunt, T.K. Infection and oxygen. In Problem Wounds: The Role of Oxygen; Davis, J.C., Hunt, T.K., Eds.; Elsevier: New York, NY, USA, 1988; pp. 1-16.

78. Cianci, P. Advances in the treatment of the diabetic foot: Is there a role for adjunctive hyperbaric oxygen therapy? Wound Repair Regen. 2004, 12, 2-10. [CrossRef]

79. Wattel, F.; Mathieu, D. Oxygen and wound healing. Bull. Acad. Natl. Med. 2005, 189, 853-864.

80. Knighton, D.; Halliday, B.; Hunt, T. Oxygen as an antibiotic: The effect of inspired oxygen on infection. Arch. Surg. 1984, 119, 199-204. [CrossRef] [PubMed]

81. Knighton, D.R.; Halliday, B.; Hunt, T.K. Oxygen as an Antibiotic. Arch. Surg. 1986, 121, 191-195. [CrossRef]

82. Driver, V.R.; Yao, M.; Kantarci, A.; Gu, G.; Park, N.; Hasturk, H. A prospective, randomized clinical study evaluating the effect of transdermal continuous oxygen therapy on biological processes and foot ulcer healing in persons with diabetes mellitus. Ostomy Wound Manag. 2013, 59, 19-26.

83. Weissenbach, M.; Clahsen, T.; Weber, C.; Spitzer, D.; Wirth, D.; Vestweber, D.; Heinrich, P.C.; Schaper, F. Interleukin-6 is a direct mediator of T cell migration. Eur. J. Immunol. 2004, 34, 2895-2906. [CrossRef]

84. Wright, H.; Cross, A.L.; Edwards, S.W.; Moots, R.J. Effects of IL-6 and IL-6 blockade on neutrophil function in vitro and in vivo. Rheumatology 2014, 53, 1321-1331. [CrossRef]

85. Pandit, A.S.; Faldman, D.S. Effect of oxygen treatment and dressing oxygen permeability on wound healing. Wound Repair Re-gen. 1994, 2, 130-137. [CrossRef] [PubMed]

86. Gallagher, K.A.; Liu, Z.-J.; Xiao, M.; Chen, H.; Goldstein, L.J.; Buerk, D.G.; Nedeau, A.; Thom, S.R.; Velazquez, O.C. Diabetic impairments in NO-mediated endothelial progenitor cell mobilization and homing are reversed by hyperoxia and SDF-1 $\alpha$. J. Clin. Investig. 2007, 117, 1249-1259. [CrossRef]

87. Goldstein, L.J.; Gallagher, K.A.; Bauer, S.M.; Bauer, R.J.; Baireddy, V.; Liu, Z.J.; Buerk, D.G.; Thom, S.R.; Velazquez, O.C. Endothelial pro-genitor cell release into circulation is triggered by hyperoxia-induced increases in bone marrow nitric oxide. Stem Cells 2006, 24, 2309-2318. [CrossRef] [PubMed]

88. Gallagher, K.A.; Goldstein, L.J.; Thom, S.R.; Velazquez, O.C. Hyperbaric Oxygen and Bone Marrow-Derived Endothelial Progenitor Cells in Diabetic Wound Healing. Vascular 2006, 14, 328-337. [CrossRef]

89. Thom, S.R.; Bhopale, V.M.; Velazquez, O.C.; Goldstein, L.J.; Thom, L.H.; Buerk, D.G. Stem cell mobilization by hyperbaric oxygen. Am. J. Physiol. Heart Circ. Physiol. 2006, 290, H1378-H1386. [CrossRef]

90. Armstrong, D.G.; Jude, E.B. The Role of Matrix Metalloproteinases in Wound Healing. J. Am. Podiatr. Med. Assoc. 2002, 92, 12-18. [CrossRef] [PubMed]

91. Armstrong, D.G.; Gurtner, G.C. A histologically hostile environment made more hospitable? Nat. Rev. Endocrinol. 2018, 14, 511-512. [CrossRef] [PubMed] 